This is an Accepted Manuscript of an article published by Taylor \& Francis in Women A Cultural Review 29:2 2018 on 25 May 2018 available online:

https://www.tandfonline.com/toc/rwcr20/29/2

doi.org/10.1080/09574042.2018.1447039

\title{
The special relationship and the allure of transatlantic travel in the work of Elinor Glyn
}

\section{KAREN RANDELL}

ALEXIS WEEDON

\begin{abstract}
Winston Churchill famously said the United Kingdom and the United States of America had 'special relationship'. This paper takes a look at Elinor Glyn's Atlantic travel in her life and in her novels, and her visits to America drawing on her archives, memoir, magazine articles and contemporary newspaper reports of her trips.

Her novel Six Days (1924) was adapted into a popular silent film which was exhibited in Europe and the USA. It's combination of love and romance, transatlantic travel on the Cunard liner, secret military mission and political co-operation is taken an example how the special relationship between the USA and the UK has been depicted in romance novels. It draws parallels between the movies 6 Days (Goldwyn, Brabin, 1923) and Titanic (Cameron, 1997). This paper was a keynote at the Love Across the Atlantic conference, University of Roehampton, June 2017.
\end{abstract}

Keywords: Elinor Glyn, Romance novels, Three Weeks, Six Days, American divorce, William Randolph Hearst, Vanderbilt, Olympic, Titanic, liner, Cunard White Star, transatlantic travel, 1912, 1920s

In June 2017 we were invited to give the keynote address at the Love Across the Atlantic conference held at the University of Roehampton. ${ }^{1}$ Elinor Glyn seemed like

\footnotetext{
${ }^{1}$ Many thanks to Deborah Jermyn for inviting us to present at this one day conference, organised by the Sex, Gender and Sexuality research group, University of Roehampton and New College, University of Alabama.
} 
the perfect subject for a keynote that would offer discussion and debate on the way in which the contemporary notion of the 'special relationship' between the USA and the UK was, as we see it, predicated on love, rather than politics. ${ }^{2}$ What follows is a version of that keynote made less idiosyncratic but keeping with the nuances and amusements of our own particular approaches to exploring this fascinating and prolific writer.

\section{[[insert section break/gap]]}

In her memoir, Elinor Glyn, the British romantic novelist, filmmaker, glamour icon and business woman, recalled her first trip to America in 1908:

it seemed a very big adventure to be thus travelling about by myself, in the role of "Elinor Glyn the famous authoress", instead of in the company of my husband ... I felt independent and gay...Until that moment I had been merely a private person, who happened to write books when she felt inclined.(Glyn 1936: 138)

In 1907 Glyn had immediate popular success in Britain with her eighth novel, a popularity which travelled to the states where it got caught up in the heated debate on marriage laws. Her novel entitled Three Weeks was about an affair between a Balkan Queen and young Englishman. The mix of royalty, old Europe, English aristocracy and Elinor's own personal beauty and history were an attractive combination for the newshounds who met her. As soon as Cunard's Mauritania docked in New York, she began to learn:

It appeared that the most fantastic stories had been printed while we were yet at sea. I myself was the heroine of Three Weeks, it was said, and one paper even published a number of names (derived from the "Peerage ", I imagine) of probable "Pauls ". This avalanche so confused me that I fear I had no sensible answers ready to the usual pertinent questions: "What did I think of America? What were my views on American divorce? How long was I going to stay? What had I come for? Would I tell the struggles of my early life? How did I react to the change from obscurity to fame? " (Glyn 1938: 139)

Glyn was accompanied by Consuelo, Duchess of Manchester, and they were invited to Mrs Vanderbilt's stately home at Hyde Park on the Hudson. As she said in her

\footnotetext{
${ }^{2}$ The phrase first used by Winston Churchill in 1946
} 
memoirs, she had a love of 'such things as fine buildings, splendid rooms, rich silks and blazing jewels, adorning handsome, soigné men and lovely, carefree women.' (Glyn 1936: 339). A love which had been fashioned in Europe, now met the moneyed families of old New York. Elinor was awe-struck by the house. Anthony Glyn her grandson explained:

A long flight of marble steps led from the drive to the front door, and on every third step was a footman in knee-breeches and with powdered hair drenched in the pouring rain. The guests were ... lead through a series of salons to a great drawing room where their hostess was waiting to receive them, magnificently gowned and wearing some fifty thousand pounds' worth of pearls and long white kid gloves. (Glyn 1955: 137)

Elinor was less enamoured by the conversation, quips went unanswered and there was little of the dalliance she had come to expect in English country houses. Later when Glyn went to California she became an intimate of William Randolph Hearst and 'upholding equally the need for joyous earthly love and its fulfilment' accompanied his mistress Marion Davies, she saw there the 'pagentry and show' which the Chief's castle had in abundance. America simply dazzled her, and she embraced it. (Glyn 1936)

The trip in 1908 was not the first time Glyn had crossed the Atlantic. As a child of eight she had come from Canada to Jersey leaving her Ontario ranch to stay at Richlieu, a manor house on the channel island, with her step-father. This early voyage had brought the family from a French Canadian rural existence in new world to a middle-class upbringing in the old. Underpinning this first transatlantic crossing were both economic necessity and marriage, two imperatives which linked this crossing with her many subsequent ones.

In fact, when in the new century Elinor sailed from England to New York, she did so as the family breadwinner. Having married into the aristocracy, she found that her husband had given her entré into this privileged world but at a price. While Clayton Glyn gambled away his fortune, Elinor took up her pen to pay the household bills and put her observations into her writing. A year later she published Elizabeth visits America. Her young heroine writes home to her: Dearest Mamma,--

America is too quaint. Crowds of reporters came on board to interview us! We never dreamed that they would bother just private people, but it was because of the titles, I suppose. ... [Octavia] said she wanted to see all the 
American customs and if talking to reporters was one of them, she wanted that, too. So she was sweetly gracious and never told them a word of truth. (Glyn 1909)

Discriminating between truth and falsehood, sincerity and kindness was confusing: In her autobiography Elinor vividly recalled how: '[T]his avalanche [of questions] so confused me that I fear I had no sensible answers ready...' So the press told stories and she tried to correct them. (Glyn 1936: 139)

\section{[Subhead] The effect of Three Weeks}

Her book had hit on a controversial topic: she wrote later that 'Whether you were "for" or "against" Three Weeks was quite an important matter in the US' that spring of 1908 (Glyn 1936: 163). The dispute which raged in public in America was about what was acceptable grounds for divorce. These differed from state to state and there was no uniform USA divorce law causing people to migrate to find their settlement (Ridley 1991). The discussion was provoked by the government's second statistical study on divorce which showed that in the previous twenty years divorces had increased at around 30 per cent every 5 years. Glyn's novel hinted at some of the causes: a violent marriage, an absence of children, drunkenness, civil unrest -- leaving out only bigamy and desertion. Reviewing the play by the 'talented authoress herself' that toured America in 1909-10 a Nabraska newspaper said: 'No book ever written has aroused so much discussion pro and con on both sides of the Atlantic Ocean as this powerful story of the unfortunate Queen, who gave her life in payment for a great happiness and yet by the sacrifice lifted a nation out of despair and at the same time inspired a man with the noblest thoughts and ambitions' (The North Platte 1909). The scandal and romance no doubt added to the audience who in turn fell in love with the 'scenes of old Europe' and swooned like Paul over the bed of roses in beautiful a Venetian apartment. 

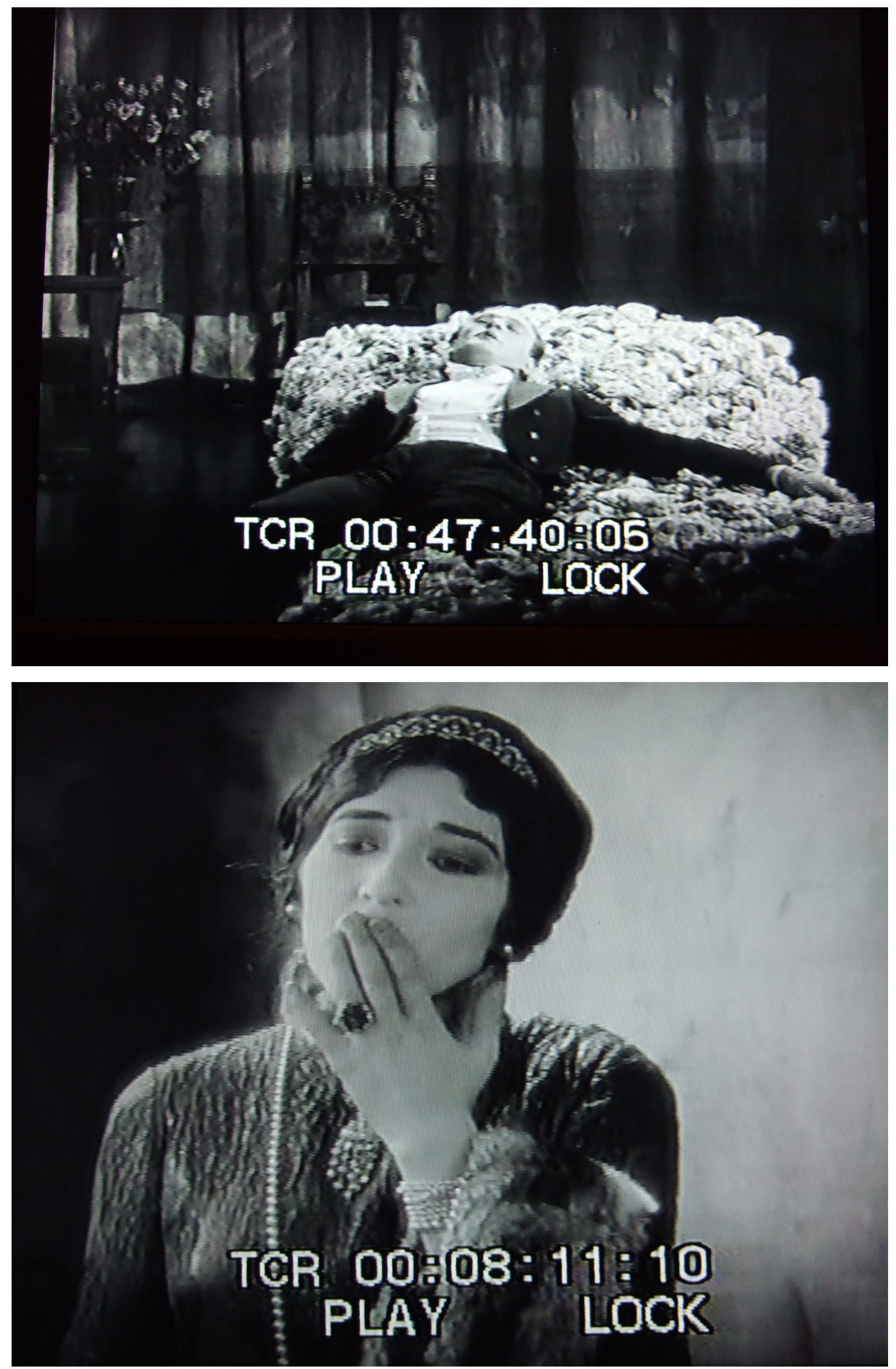

[[Insert fig 1]] Figure 1. Two frames from A Romance of a Queen (Crosland, MGM 1924) the film adaptation of Elinor Glyn's Three weeks (1907). Paul Verdayne 
reclines on a bed of roses in the Venetian apartment and the Queen demonstrating her love for her people. Frame grabs from author's copy of A Romance of a Queen from Gosfilmofond archive, Moscow.

Yet romance and its special relationship Glyn saw transcended class She defined that 'special something' in a person which gave them a sexual allure and charisma as 'it'. Anyone could have 'It'. 'It' was daring, self-confident, playful, a swagger just kept within social bounds by 'individual discipline'. It could be self-taught. Glyn, herself, had 'it' and found 'it' in when she went west to the Nevada gold mining camp. The papers reported:

In the ... biggest gaming place in the camp, she wagered [two hundred dollars] on faro [sic]. She lost and she repeated the bet three times before she won a bet, leaving the place [one thousand dollars] to the good.... [her tour continued round the] tenderloin of Rawhide, a half-dozen dance halls and at least six hundred women in this street.... Not a thing happened to mar the sight-seeing trip except a prospector and a gambler. The prospector took two shots at the gambler as he made his escape around the corner of a building.' (New York Times, 1908)

George Graham Rice, owner of the news bureau, later wrote that the incidents were a set up. "Of course, the "murder" of these two gamblers, during the progress of a cardgame for sensationally high stakes and in the presence of the authoress of "Three Weeks," made fine front-page newspaper copy' (1913: 232). Glyn corrected the inaccuracies where she could. But she was touched by their hospitality. Her grandson recalled:

One man had ridden ninety miles across the desert to fetch some yellow daisies, the only flowers procurable, to decorate the centre of the oilcloth-covered table. Elinor was almost in tears. Ninety miles, there and back, across the desert, just to fetch her some flowers, and the man never revealed which was he. ..... [Glyn 1955,1489]

She never forgot the Rawhide miners.

"I have traveled from Budapest to Bombay, ..., and there are few experiences I have not had and few people I have not met, but of them all Rawhide is the greatest" she said to the waiting journalist (The Washington Times, 1908) 'They seemed to her the embodiment of everything that was best in the New World. 
She set the climax of two of her novels in the Nevada gold-fields.' (Glyn 1955: 149) Adventure, speculation, wealth, and men made handsome with hope and hard physical work. Europe, she said, did not have men like these.

The effect of the continent on Glyn was felt by her readers - Arnold Bennett looking back in 1911 humorously noted this was a watershed: 'To-day, one man in one column and one day will polish off what [it took five of us to do in]... the distant past ... before America and Elinor Glyn had discovered each other' (Bennett, 1917) What she found and what she experienced had converted her.

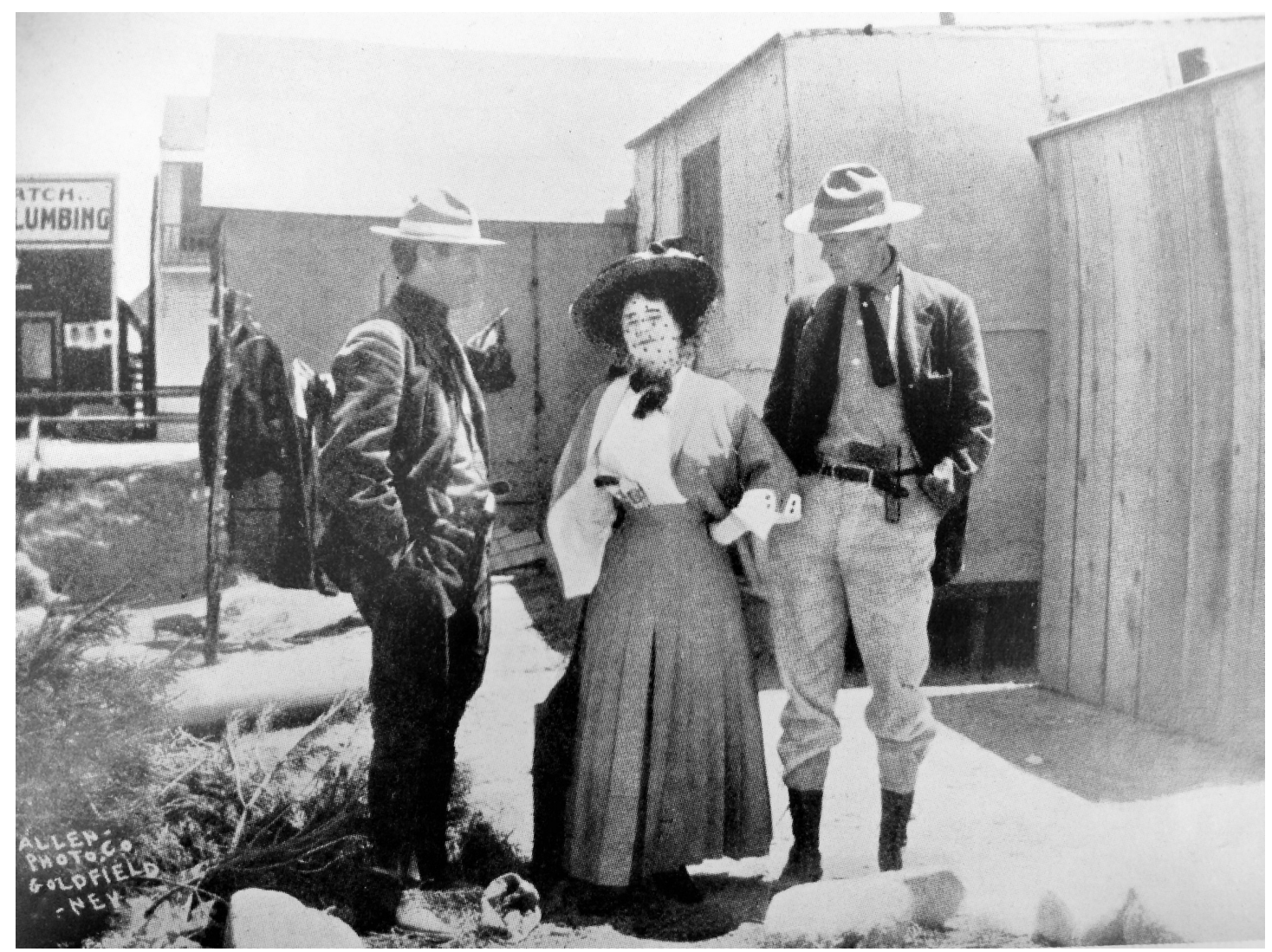

[[Insert fig 2 here]] Figure 2. Elinor Glyn and the Rawhide miners. Photograph from Anthony Glyn's Elinor Glyn, a biography, Hutchinson (1955) copyright Random House.

\section{[Subhead] The allure of transatlantic travel}

The glamour of Hollywood was a huge draw for Glyn as it was for millions of film goers in the UK in the nine-teens and 1920s. Cinema magazines such as Picture Goer enabled the general public to fall in fascinated love with the stars and another special transatlantic relationship was born; our love affair with Hollywood. Its glamour was increased and brought nearer to us by transatlantic travel's connection to Hollywood. 
The White Star/Cunard line was the shipping line of choice and its opulent first class accommodation and public rooms transferred the five-star appeal of sophisticated city hotels to sea travel.

If the Titanic (as we will discuss later) was the 'ship of dreams', the Olympic was the ship of stars, bringing Charlie Chaplin, Mary Pickford, Douglas Fairbanks Jnr and celebrity Royals such as Prince Edward, the Prince of Wales to and from Europe and the USA. For instance, on July 211920 Cary Grant (then Archibald Leach) travelled to the USA to start his Hollywood career on the Olympic alongside Fairbanks and Pickford on the return journey of their honeymoon. For Glyn the allure of glamorous travel, the salons, the cabins and the bars is matched only by the magnetism of those travelling, and in particular, the wealthy American. A short novel by Glyn, Six Days, published in 1924 has its first six days of the narrative set on the Olympic. By 1924, Glyn was an expert and frequent traveller and had taken twelve transatlantic voyages on the White Star/Cunard luxury liners and had sailed on six different ships, including Titanic's sister ships, the Lusitania and the Olympic.

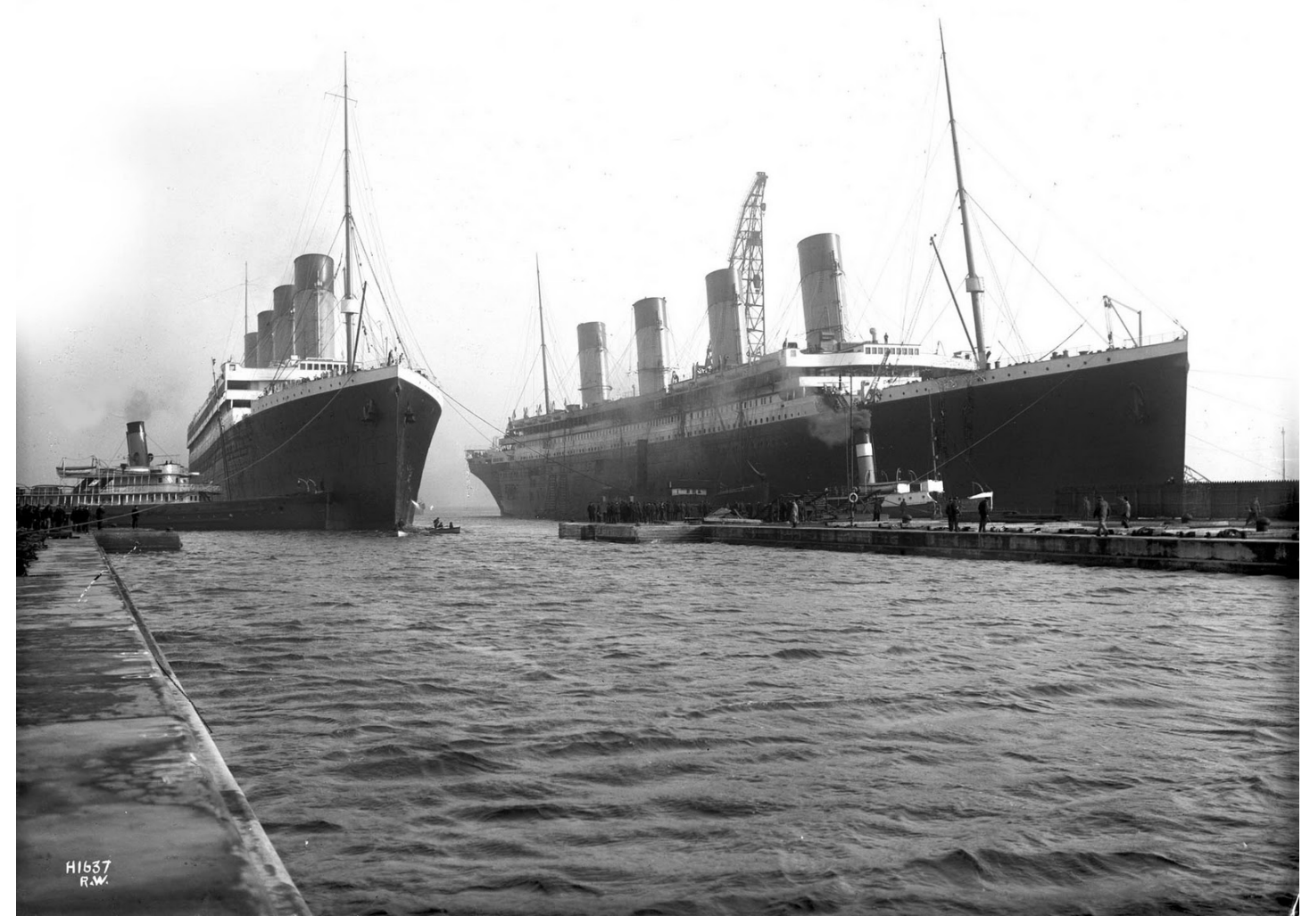

[[Insert fig 3 here]] Figure 3 Titanic (right) and Olympic (left) in the Thompson graving dock while Titanic is under construction, 1912. Robert John Welch (18591936), official photographer for Harland \& Wolff Public domain at 
https://commons.wikimedia.org/wiki/File:Olympic_and_Titanic_crop.jpg (accessed 30 October 2017)

RMS Olympic was the lead ship of the Cunard White Star fleet from 1911 to 1935. During WWI it was used as a troop ship and earned the name, Old Reliable. It was designed and built by Harland and Woolf and contained, to quote the advertising, a Georgian smoking room, 'luxurious cabins with private bathrooms' and 'luxurious dining rooms with an a La Carte restaurant.' There was also, a 'veranda café with palm trees', a swimming pool, Turkish bath and gymnasium' and in 1913 a Parisian café was added (along with more lifeboats). The journey on these fast steamers in fact only took four days during the early nine-teens, the speed necessary to carry fresh provisions from one side of the Atlantic to another, and of course, most importantly the post. However WW1 marked a change in the business of transatlantic travel as in 1917 the USA required a literacy test for immigrants and in 1924 national quotas were enforced. So, in the early 1920s the voyage was slowed down to accommodate the increasing number of first class and then second class travellers who enjoyed the vacation/holiday experience of sailing from one continent to another.

So Elinor Glyn's love affair with the United States was well defined by the time she published this novel. The story focuses on a young, rich American heiress, Laline Lester who with her aunt is travelling from New York to Europe on the Olympic for her first tour. In her party is the British Captain Jack Lumley who had served with the Guards during WWI. Looming in the wings is American Major David Lamont, who was part of the US expeditionary force and was attached to Captain Lumley's battalion in 1918. Major Lamont is travelling on the ship to carry out a secret mission, sanctioned by the President himself. Of course David and Laline fall in love during the voyage and the romance continues on dry land after this initial frisson, ending, of course, in marriage (Glyn 1924). 


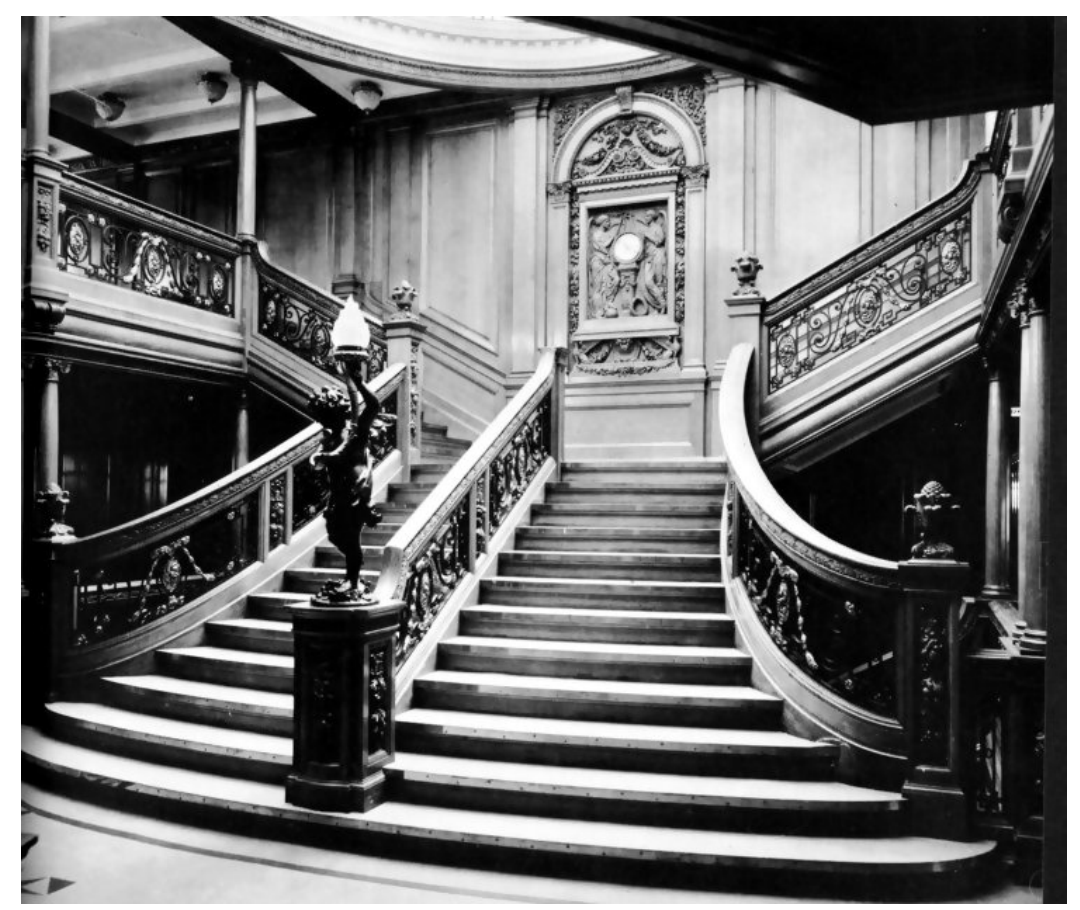

[[insert fig 4 here]] Figure 4 Grand staircase of the Olympic. photographed in 1911 by William H. Rau. Public domain at https://commons.wikimedia.org/wiki/File:Grand_Staircase_aboard the RMS_Olymp ic (William_H. Rau 1911).jpg (accessed 30 October 2017)

\section{[Subhead] Six days of transatlantic romance}

As many journeys do, this transatlantic crossing became a rite of passage for Laline.

On day one the novel states:

Laline was looking for something in life-she did not know what. All the men she had met she could rule. She danced with them, listened to their love declarations, realized that they were all the same and then troubled herself no more about them. She was accustomed to their devotion, which contained no thrill. (Glyn 1924: 11)

David Lamont on the other hand, was more experienced at life and was looking for a quiet passage across the Atlantic so that he could focus on his secret mission and prepare himself for what might lie ahead, he:

....arrived at the dock early on the Wednesday and went on board the Olympic before the rush began, and he was smoking a quiet cigar on the top deck where no one noticed him, when, with all the paraphernalia of rich Americans leaving for Europe, Laline and her aunt and Jack Lumley, came across the gangway (1924: 20). 
Glyn effortlessly includes the excitement, glamour and excesses of transatlantic first class travel within the narrative creating a strong visual image for the reader that also enables us to gain an insight into the way in which upper class customers travelled between these two countries.

On day two Laline is,

...so glad that she had had this lovely trousseau of steamer clothes. A change for every day of the six days, and each tweed, or woolly costume, and great, enveloping fur-trimmed wrap was more becoming than the last! (1924:25)

And she takes a 'lovely hot bath' (1924: 38) before deciding that:

This morning she would wear the mauve wool shot with grey, and she would tuck in a bunch of Parma Violets. Countless boxes of flowers reposed in the chilled chamber waiting to be brought out fresh for each day of the whole voyage (our italics 1924: 25 ).

A chilled chamber for flowers and a hot bath, let's just consider that for a moment--because what is particularly significant in this novel is the way in which Glyn does not engage with issues of class. The novel centres around wealth and status, any working class characters appear only as maids, valets and waiters and have no storyline of their own. To read Six Days with no cultural context assumes a complete absence of anyone other than the first class passengers on board the ship. Of course as we know this was most certainly not the case, in fact at least 1,000 of the passengers on board would have been steerage passengers, where bunks were placed in basic dorms or large bedrooms and bathrooms consisted of one sink with pumped water and one toilet and were, of course, shared.

Drew Keeling's work on passenger travel on the White Star/Cunard line from 1908-1935 tells us that the ships were designed with a particular logic '...of using different vessel sections to accommodate tourist, migrants, and freight, [and that this] applied across all the major passage lines' (Keeling, 2008a: 14 and 2008b). He states that '...shipping lines were in the business of maintaining frequent and regular schedules... as part of their government mail contracts and for their prestige-bringing luxury class tourists and business travellers, but that they found migrant traffic to be an indispensable element within a cluster of jointly provided transit services (2008a: 18 see also Keeling 2012: 234-38). Migrant travellers then were an essential means of filling the large vessel spaces below the upper decks most desirable to tourists, senior government officials and businessmen (2008a: 18) like the characters in Six Days, and 
indeed like Glyn herself and other writers such as C. S. Forester, Clemence Dane and Hugh Walpole who were lured to Hollywood. ${ }^{3}$

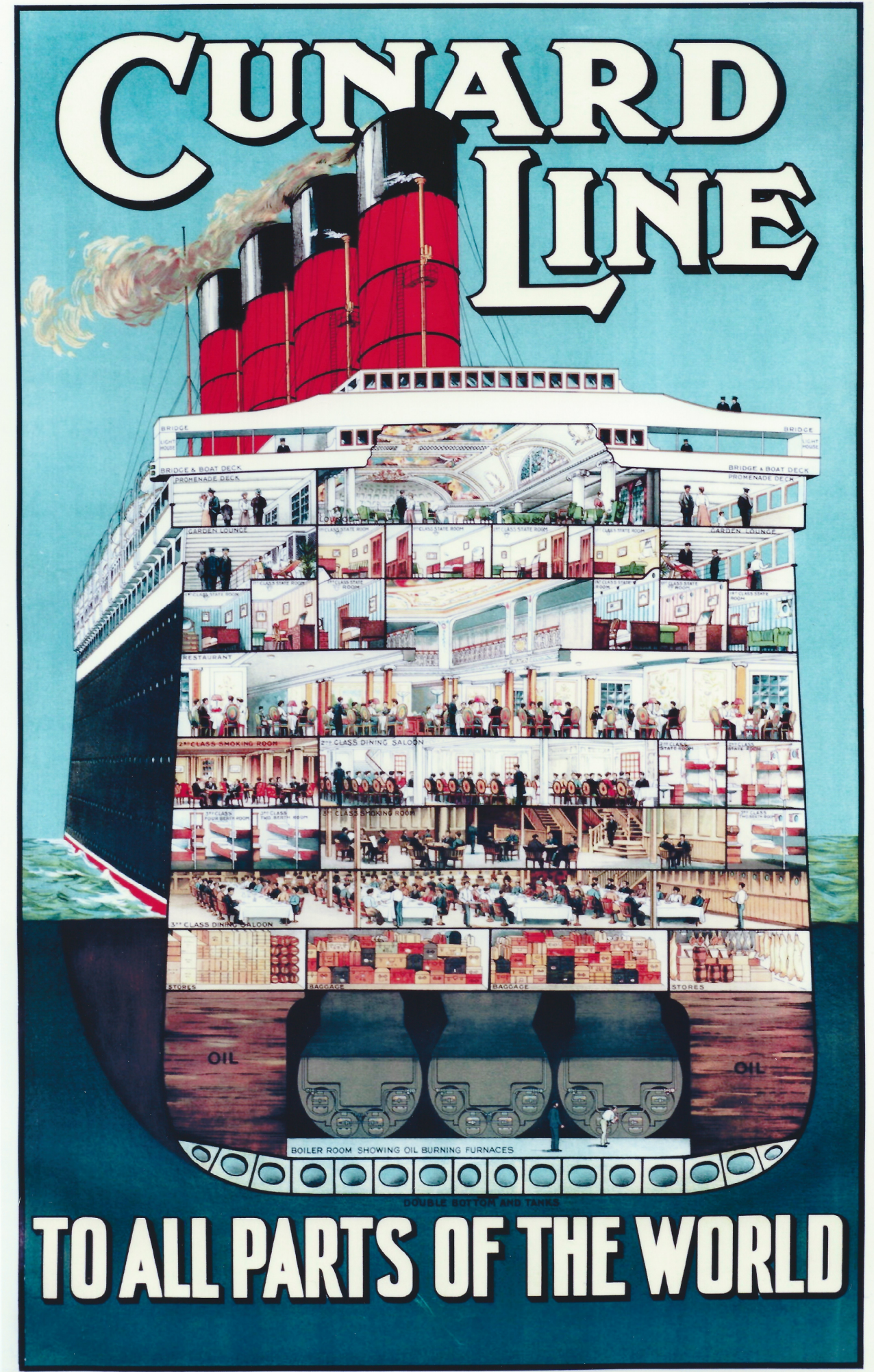
${ }^{3}$ Some authors passage was paid for by the Studios, others had to fund themselves
and travelled less luxuriously. 
[[Insert fig 5 here]] Figure 5 Cunard poster of cross section of Aquitania 1921. From a copy in the author's possession. ${ }^{4}$

Glamorous advertising of the ships focused its appeal on the minority of wealthy passengers who travelled first class also rendering the steerage passengers absent. As Keeling points out, 'Being a transporter of large numbers of migrants was not a source of prestige or public relations in the way the carrying of famous wealthy celebrities aboard mammoth state-of-the-art liners with luxuriously appointed upper decks was (2008a: 14 and also 2012; 237). However, it was not the first class passengers who made the White Star/Cunard line rich it was the wave of immigration.

Between 1860 and 191414 million Europeans immigrated to the USA these numbers increasing from 753,000 a year in 1899 to $1,745000.000$ in 1914 . Resulting in the revenue increasing from immigrant fares alone from $\$ 14.2$ million in 1899 to \$28.2 million in 1914. Compare that revenue to the \$10.4 million taken in 1914 for first class passengers and you can understand that without the migration and travel of working class travellers White Star/Cunard would not have economic success.

Although the line did not use lavish advertising to directly sell to their main source of income they did advertise in newspapers and promote the good accommodation that was provided for steerage passengers as they waited to sail. For instance, Keeling notes that:

In Liverpool by 1903, Cunard had a 'complex of houses' that could accommodate two thousand passengers awaiting departure in 'ten bed dorms', with good sanitation and food, provision of separate Jewish diet, and staffs of foreign origin who spoke the appropriate languages (2008a: 15, also Kraut 1994 and Taylor 1971).

When you consider that the average home in the UK and the USA did not have an inside lavatory this is quite some provision. In 1909 a magazine article in the New York Herald advertised travelling as the '... aristocracy of steerage' on the Lusitania and Mauretania with 'all-closed berth' for steerage passengers (1909: 12). We can see that the liner companies were swift to accommodate economic and cultural change and to keep transatlantic travelling in the public eye.

\footnotetext{
${ }^{4}$ See also https://en.wikipedia.org/wiki/File:Aquitaniaposter.PNG
} 


\section{[Subhead] The beginnings of the 'special relationship'?}

This class structure in the narrative of Six Days jars with the reality of transatlantic travel and offers some insight into why millions of Europeans immigrated to America, a country that offered the hope of an egalitarian life, the possibility of making money and living the American dream particularly after the devastations of WWI in Europe where hope was in increasingly shorter supply.

During the war Glyn wrote for the American magazines from Paris and drove out to the front. In one of her articles for The Novel Magazine, she returns to the epistolary form narrating her observations of visiting the US Special Operations Overseas through the eyes of her heroine. At St Nazaire, the young English girl meets her American allies and she gushes: "whenever the Americans do anything, they do it well, they are the cleverest things on this earth, I think' (Glyn 1913). It is similar tone to her earlier Elizabeth who naivély wrote to her Dearest Mamma --.

Everything is "colossalised"--events, fortunes, accidents, climate, conversation, ambitions--everything is in the extreme-- Even in their hospitality they are ... simply too kind and generous for words. (Glyn 1909) As a tale, 'Elizabeth's Daughter' captured the moment for her readership and was featured on the cover in an illustration with the stars and stripes, soldiers in uniform, and inside a camouflaged ship docking in France.

Yet Glyn was without illusion when it came to the motives of many crossAtlantic relationships. Marriage was, or could be, an economic and political choice, and love the complicating factor. It was the export of an aristocratic title, of manners and old world associations in exchange for the wealth only found in America. In the old world responsibility came with wealth because wealth was linked to land and the people working on it. American wealth was associated with trade and free from such ties. This perception underlies Glyn's heroine's observation to her mamma about the women she meets.

[They] are not the least interested in politics ....and hardly any of them have the duties we have to do, like opening bazaars ... and being heads of all sorts of organisations, nor do they have quantities of tenants' welfare to look after, or be responsible for anything. (Glyn 1909)

So even in Glyn's fiction, at this early stage the 'special relationship' was both military and romantic. Yet it became increasingly economic as the century progressed: wooing America was always part of the British economic strategy. 
Winston Churchill said famously of his daily letters to Roosevelt for arms and money during WW2 'No lover ever studied every whim of his mistress as I did those of President Roosevelt' (Colville, 1985: 624). Glyn too wooed her public on both sides of the Atlantic reaping her economic rewards. She wrote article upon article for the editors of American magazines, and gained the favourable impression of the American press. The magazines confirmed her success saying Glyn's profits were 'balance sheet facts' for 'Three weeks' and 'Six Days' were 'money magic' (Picturegoer https://archive.org/)

In large part due to the war the economic situation was very different at the time of her first visit in 1908, her second stay from 1924, and on her last return voyage in 1929. Postwar German reparations and British war debts were to America, and Britain borrowed heavily from New York in the twenties. British exports reversed, from an average yearly 1.9 per cent increase in exports to industrial countries at the time of her first visit to, by the thirties, the negative figure of 4.7 per cent per year. The British withdrew investment from abroad, abandoned the gold standard and monetary instability spread. In 1929 the effect of the turbulence lead to the crash and Glyn's contracts dried up. When Keeling looked at of travel across the Atlantic from 1885 to WW1 on the Cunard liners he noted the pattern of depression and growth and concluded 'the timing of moves to (and from) America was driven mostly by the economic factors in [the country].' (2008a:8) Glyn was no exception to this rule. Travelling in 1924 from Paris to New York on the Aquitania under contract with Famous Players Lasky, Glyn was a widow with her own small income from her writing and great expectations of Hollywood. As with all American special relationships hers depended upon personal connection and she was in William Randolph Hearst's 'set'. She made many personal and romantic friendships and found it difficult to follow Sir Gilbert Parker's advice and 'remember business is business.' For her, and for other writers, the rewards for Hearst's writers were great: 'Big money is paid for stories and scenarios to-day' ... '- a good bit bigger than is being paid in [shop girls'] salaries' said Glyn (1922: 23). Yet she admired the American girls and their freedoms: In the magazine Britannia and Eve, she wrote 'England is a man's country, not a woman's, and .... America is a woman's country. Woman is supremely powerful there' (Glyn 1929: 16-17). The comparison made good copy. Glyn was paid 200 dollars a week for two 600 word articles when she arrived. By July 1929 she was writing six a week. It was impossible for British magazines to match such sums as 
payment. (RUA MS 4059 May, 28, 1924 and Box 5. July, 24, 1929)

The large distance between Glyn and her married daughters in Britain, her agents and lawyers on both American coasts, was not simply geographical, but also cultural. Her team of professionals included her sons-in-law, and knowledgeable as they were in their own jobs, they were not experienced at all in dealing with USA film studios, especially from such a distance as the UK. While the liners, undersea cable and telegraph had brought Britain and America closer together, communicating with home by delayed letters and misunderstood telegrams swiftly lead to distrust, a danger which has always bedevilled the special relationship. Prime ministers and presidents have fallen out too, leading to 'unanswered phone calls' and actions, campaigns military or economic - unconfessed, unspoken, like broken confidences or hidden affairs - undermined the relationship.

The rivalry, perhaps too a little jealousy, in the special relationship is caught in Harold Macmillan's 1943 characterization when he likened it to the wisdom of old Greece aiding the zeal of new Rome. Elinor represented wise old Europe admiring the youthful zeal of the new generation in America, or in her terms, the experienced flirt in awe of the freedoms and liberties of the flapper. Glyn had always combined her personal and professional relationships and her family were a little alarmed by her unilaterally engaging John Wynn as her agent. Glyn's daughter Juliet came over to investigate only to be equally seduced by Hollywood, she learned scriptwriting and started her own agency. Yet every special relationship has to be for the benefit for both parties, so Juliet worked for her mother, and ensured her mother's copyrights were assigned to her company and an annuity put aside for her old age.

\section{[Subhead] The continuing glamour of the transatlantic voyage}

The notion that America had opportunities for woman was a strong one for Glyn and the female agency that she perceived in the teens and 1920s can be seen writ large in the poster for Six Days which shows the flapper on the prow of the ship like an erotic figure head (Figure 5). 


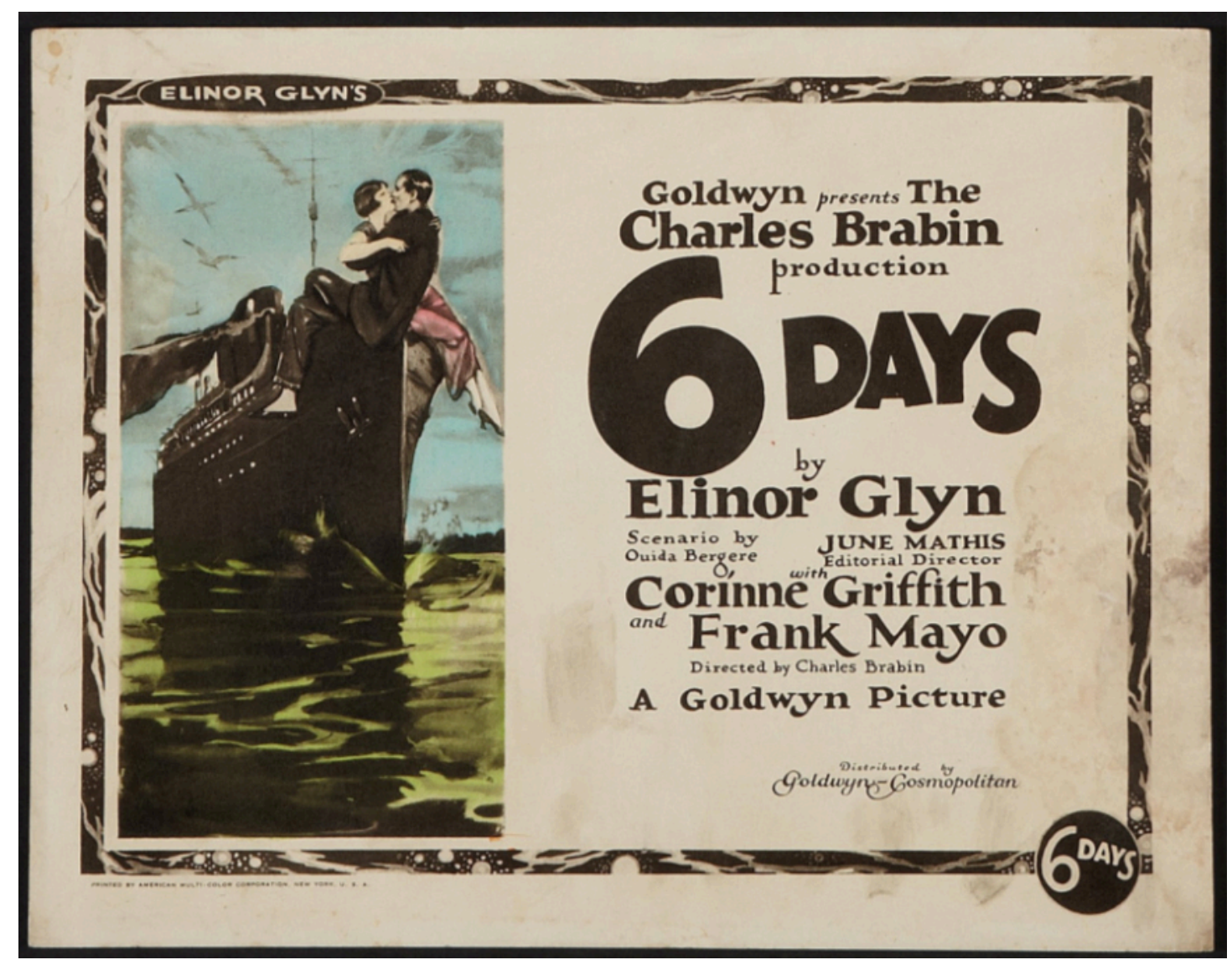

[[insert fig 5 here]] Figure 5. Lobby card for Charles Brabin's film adaptation of Elinor Glyn's Six Days showing its similarity to the movie poster for James Cameron's Titanic (1997). Reproduced by kind permission of Heritage/Heritage.com.

Elinor Glyn's Six Days was set on the Cunard Olympic, the sister ship of the Titanic and indeed it became even more popular to sail on it after Titanic sank as travellers wanted to experience the morbid voyeurism as well as the voyage of the fated ship. Glyn's novel foreshadows the later films that fictionalise that tragic journey and in particular it is difficult to read her novel without imagining scenes from James Cameron's Titanic (1997).

When the central character, Rose (Kate Winslet), her fiancée Cal (Billy Zane) and her mother (Frances Fisher) arrive at Southampton Docks with 12 suitcases and hat boxes, in their own separate chauffeured vehicle, it is easy to imagine that this is the 'paraphernalia' of Americans travelling in Europe that David Lamont, in Six Days, observed as he smoked his quiet cigar on the top deck. As Rose steps out of the car, she tips her hat and reveals her started look at the enormity of the ship, and of course at the enormity of the life ahead of her as the bored wife of a rich American. 
Around her porters rush for luggage and first class passengers are ushered aboard via wooden gangplanks to rise to the higher decks where they are met and greeted by liveried officers. The opulence of the first-class passengers, some arriving with large and small dogs, is in marked contrast to the steerage class passengers who are stopped by officials to check papers, teeth for cavities and heads for lice.

This moment highlights the inequalities that will be apparent on board as the first class passengers embark unencumbered by orderlies checking their beards for lice or their teeth for cavities. In fact the first class passengers can take on their long haired dogs with no checks whatsoever. The pathology of the ship, as Gaylyn Studlar describes is emphasised here: 'Not only must the ship sink in order to free Rose, but it also must sink because it is pathological. Its pathology, social and spiritual, is represented architecturally by the ship's absolute separation of the classes' (Bergfelder and Street 1994: 159). The very structure of society outside the ship is designed into the architecture of the ship so that when the ship goes down, those at the top are saved and those at the bottom perish. It is well recorded that of the 2,223 passengers on board Titanic only 329 were first class, 199 of whom were saved, including Elinor Glyn's sister, Lucy, Lady Duff-Gordon a well-known fashion designer. Of the 1,517 lives lost $85 \%$ were second class, steerage and crew. Reading Six Days we can be lured into a glamorous and safe world in which no one will perish because those that would don't exist at all. ("Titanic" Disaster, 1912)

For the millions who crossed the Atlantic the journey was a new beginning, those who returned more often than not returned to gather family members to join them in their new life. So a return journey was a hard one because while the traveller had been away the old world had moved on. When Glyn came back in 1929 she tried to revive the British film industry spending her fortune on two films: Knowing Men and The Price of Things (1930). But what she had learned in Hollywood did not translate back home. While Glyn knew her men - and the parties on and off screen in Hollywood were put in to her talkies - her movies did not reveal to a benighted British industry the true virtues of character, stardom and box-office first nights. In Knowing Men, her hero may have found his rich American heiress, but Glyn's fortune was spent.

Perhaps, with our tongue in our cheek, we can sum up the special relationship that exists between USA and the UK by going back to the on-board romance of Laline and David on the Olympic and using Glyn's romantic ideal to think about the draw 
and the allure of our transatlantic connection: After three days David is still trying to keep his stand-off position but: 'The fight went on...He talked when he was absolutely dragged into talking with her... But underneath he was growing to be profoundly affected by her; and, as for the girl, by the last evening before they got into Cherbourg, she had fallen deeply in love with him' (Glyn 1924: 30). His ambivalence cannot withstand what the last two words of the novel tells us is the only thing that really matters in a special relationship is: "True Love."

Alexis Weedon asks us to consider in the introduction to this journal whether we can consider Elinor Glyn as a pioneer. There is much to suggest that she was; a self-made woman who used the trope of love and romance to explore many pertinent contemporary issues that effected being a woman in the late $19^{\text {th }}$ and early $20^{\text {th }}$ century: divorce, motherhood, employment, marriage, relationships and health and beauty. Her work embodies the pertinent issues for western woman of her time and gives us insight into the significant shift in woman's status. Her travels across the ocean ensured that a narrative which might have stayed idiosyncratically English was disseminated widely through her Hollywood successes and opened a debate about what it was to have not just 'it' but to be a working woman in a man's world.

\section{Acknowledgements}

Alexis Weedon's work in this article is an outcome of the AHRC funded project Cross-media co-operation between British novelists and filmmakers in the 1920s and 1930s (AR112216)

\section{Works Cited}

Bennett, Arnold (1917) Books and Persons: Being Comments on a Past Epoch 19081911, 'Books of the Year 1911' 12 Jan 1911. London: Chatto and Windus https://www.gutenberg.org/files/15717/15717-8.txt

Bennett, Arnold (1917) Books and Persons: Being Comments on a Past Epoch 19081911, 'Mrs Elinor Glyn' 10 Nov 1910. London: Chatto and Windus https://www.gutenberg.org/files/15717/15717-h/15717h.htm\#MRS_ELINOR_GLYN

Bergfelder, Tim and Sarah Street (1994) The Titanic in Myth and Memory: Representations in Visual and Literary Culture, London: I.B.Tauris. 
Colville, John, (1985) Fringes of Power: Downing Street Diaries 1939-1955 London:

Hodder and Stoughton

Glyn, Elinor (1909) Elizabeth visits America, London: Duckworth

http://www.gutenberg.org/cache/epub/11900/pg11900-images.html

Glyn, Elinor (1909) Elizabeth Visits America, New York, Duffield. Project Gutenberg http://www.gutenberg.org/cache/epub/11900/pg11900.html

Glyn, Elinor (1919) 'Elizabeth's Daughter', The Novel Magazine, February 1919, 313.

Glyn, Elinor (1924) Six Days, Philadelphia \& London, J.B. Lippincott Company

Glyn, Elinor (1929) Britannia and Eve, August, 16-17, 142.

Glyn, Elinor, (1922) The Elinor Glyn System of Writing, Auburn: The Authors' Press. Keeling, Drew (2008a) Shipping companies and transatlantic migration costs between Europe and the United States, 1900-1914, European Business History Association Annual Conference Bergen, Norway. Working paper, quoted with kind permission of the author.

http://www.ebha.org/ebha2008/papers/Keeling_ebha_2008.pdf

Keeling, Drew (2008b) 'Transport Capacity Management and Transatlantic

Migration, 1900-1914,' Research in Economic History 25, p. 243.

Kraut, Alan (1994) Silent Travelers, Germs, Genes, and the Immigrant Menace,

Baltimore, London: Johns Hopkins University Press.

New York Herald (1909) 12 Sept, magazine section p. 12.

New York Times (1906) 'Elinor Glyn Plays Faro', 29 May.

Rice, George Graham (1913) My Adventures With Your Money R. G. Badger. Project

Gutenberg http://www.gutenberg.org/ebooks/44274

Riley, Glenda (1991) Divorce: An American Tradition, University of Nabraska Press. Taylor, Philip (1971) The Distant Magnet London: Eyre and Spottiswoode.

"Titanic" Disaster, Report on the Committee of Commerce, United States Senate. S. RES 283.

https://www.senate.gov/artandhistory/history/resources/pdf/TitanicReport.pdf

The North Platte semi-weekly tribune, 'Elinor Glyn's Three Weeks', May 14, 1909, http://chroniclingamerica.loc.gov/lccn/2010270504/1909-05-14/ed-1/seq-4.pdf

The Washington Times (1908) 'Elinor Glyn in Mining Camp enjoys genuine local color', May 29, 1908, Last Edition, p.9.

http://chroniclingamerica.loc.gov/lccn/sn84026749/1908-05-29/ed-1/seq-9.pdf 


\section{Archives}

University of Reading special collections Elinor Glyn

RUA MS 4059 Box 5. July, 24, 1929 J.V. Connolly to Miss Gertie Aherns.

RUA MS 4059, May, 28, 1924. Agreement between King Features Syndicate Inc and Elinor Glyn Ltd. 